\title{
Três Propostas de Tradução de um soneto italiano de Cláudio Manuel da Costa:
}

Euler Cruz***

Em suas Obras, publicadas em 1768, Cláudio Manuel da Costa incluiu 14 sonetos e 4 outros poemas em italiano. Os sonetos (de LXXXIV e XCVII) estão entre os 100 que iniciam as Obras e os 4 poemas ("Canzonette, Nice, Cantata II e Cantata VIII") estão entre os que as encerram. Por não conhecer tradução destes textos para o português e com o objetivo de melhor estudá-los, ocorreu-me oferecer para um deles duas versões: uma adotando a ortografia e o registro usados por Cláudio nos outros textos, em português, e outra adotando um estilo mais moderno, mais compreensível para o nosso tempo. Uma terceira versão, em prosa ou recriação em versos — mais livre mas na forma original dos poemas - poderia ser acrescentada para permitir uma melhor assimilação do conteúdo e do espírito do texto. Cada uma das traduções vem acompanhada de notas explicativas e comentários que elucidam termos, construções e figuras citadas.

O soneto aqui publicado foi um dos primeiros a ser traduzido e revela os sentimentos contraditórios do poeta em face de uma paixão não correspondida.

\footnotetext{
* Recebido para publicação em julho de 1996.

:**: Professor da Escola de Engenharia da UFMG.
} 
Esci d'ingano, ó Nice; io non t'adoro;

Chi ti parla cosi, parla sincero;

Mi piace 'l volto tuo; mi piace, è vero;

Ma non mi punse Amor col'strale d'oro.

Piangon gl'amanti ovunque; $i$ voti loro

Sono tributi d'imortal pensiero:

Or vedi; io son tranquilo, io sono altero,

Io non sento fatica, ed ó ristoro.

O nón è amore, o pur, s'amor si chiama.

D'ogni d'amor martiro l'ordin muta

Ch'in tanti cuori'l suo trionfo acclama;

Ma che mai vanta l'alma d'asoluta!

Ricanteró: Questa alma altro non brama,

Che nel incendio tuo restar perduta.

Nota: Texto transcrito "ipsis litteris" de Obras de

Cláudio Manoel da Costa, Coimbra, 1768 (primeira edição)

\section{T.1}

Sae desse engano, ó Nize, eu naõ te adoro;

Falla, quem falla assim, sem falsidade;

Acho bello o teu rosto, he verdade;

Mas naõ feriu-me Amor co'a setta d'ouro.

Por toda parte amantes daõ-se ao choro,

Fázem promessas, co' inmortal vontade;

Vê minha calma, essa tranquillidade,

Naõ me canso, nem falta-me repouso.

Naõ he amor ou, entaõ, se amor se chama

O seu martyrio a ordem tanto muda,

Que en tantos coraçoens seu reyno acclama;

Mas o que lucra a alma, se absoluta

Retracto-me: esta alma naõ mais clam

que se perder no incendio teu, sem luta.

Nota: Esta tradução respeita a grafia das palavras e tenta reproduzir o registro dos demais sonetos em português, segundo a primeira edição das "Obras". Procura, ainda, ater-se da forma mais literal possível ao original em italiano. 
Não mais te iludas, Nice, eu não te adoro.

Quem fala assim o faz sem falsidade;

És sensual e bela, é verdade,

mas o Amor hão me compra com teu ouro.

Amantes sofrem sempre e sempre choram, juram, vivem com medo e ansiedade; mas podes ver: estou seguro e calmo, durmo bem e ânsia alguma me devora.

Se é amor isto que sinto, engana-me pois é com traições e fantasias que o amor domina toda raça humana.

Mas basta. Tudo isto é ironia.

Confesso que me encantas, que te amo, que do teu fogo quero a noite e o dia.

Nota: Versão padrão século XX

\section{$T .3$}

Cai na real, Nicinha, eu não te adoro.

E podes crer que falo sério, gata.

Eu te acho um tesão, é ben verdade, mas paixão mesmo, amor? Pô, mina, isola.

Babacas se apaixonam, sofrem, choram, prometem tudo, esperam e se danam.

Eu não tô nem aí, me desencano, fico com outras, curto e caio fora.

Se isto é amor é um tipo estranho, dos que arregaça tanto que arrepia e dá um barato que não tem tamanho.

Mas esquece! Isto tudo é fantasia! Eu quero falar mesmo é que te amo e é teu fogaréu o que en queria.

Nota: Versão "galera-96" 